Ann. Biol. anim. Bioch. Biophys., I975, 15 (2), 369-374.

\title{
INDUCTION OF GESTATION DURING LACTATION IN THE SOW
}

\author{
Françoise MARTINAT-BOTTE \\ I. N. R. A., Station de Physiologie de la Reproduction, \\ 37380 Nouzilly (France) \\ I. T. P., 149 rue de Bercy, \\ 75579 Paris Cedex 12
}

\section{SUMMARY}

The moment of injection of PMSG during lactation and the size of the suckled litter at the time of treatment modify to a large extent the level of induced births : it increases if the mother suckles few piglets and when the injection of PMSG is administered late in lactation.

If one wishes to induce a gestation early in the lactation period (around the I6th day) some of the piglets must be removed from the mother before PMSG injection. Under these conditions, 76.4 p. roo of the sows come into oestrus between the 3 rd and 7 th days after hormone treatment, they ovulate. The fertility approaches that produced after an abrupt weaning 3 to 5 weeks after parturition.

Throughout lactation in the sow, oestrous cycles are usually suspended, no ovulation occurs, and the ovary is in a resting phase (PALMER et al., Ig65 ; LAUDER$\mathrm{DAL}_{\mathrm{E}}$ et al., 1965). The absence of follicular stimulation would originate from a lack of FSH release. The FSH hypophyseal content is elevated at end of lactation. But also $\mathrm{LH}$ synthesis can be stopped. The pituitary level of this hormone remains low during the period of lactation (CRIGHTON and LAMMING, I969; LAUDERDALE et al., I965; MELAMPY et al., I966) ; no hormonal assay in blood has confirmed these hypothesis.

Nevertheless, in a certain number of cases, it has been possible to induce a gestation during lactation by the use of PMSG. The results were variable, especially when attempts were made to induce gestation early after parturition (CRIGHTON, I968; I970 ; HeitmanN and Cole, I956 ; EPSTEIN and KAdMon, ig69; MarTinat et al., I972, I974).

Different factors are likely to modify the farrowing rate and the litter size after induced oestrus with PMSG during lactation in the sow. We have tried to elucidate the role of some factors (time of PMSG injection, size of the suckled litter at the time of treatment). 


\section{EXPERIMENTAL METHODS}

Large White, Pietrain and cross-bred sows received an intramuscular injection of $2000 \mathrm{Il}$ PMSG on the 16 th, 18 th, 25 th or 32 nd day of lactation ( $L_{0}$ : day of parturition).

The piglets were not separated from the mothers during the period of lactation when the females underwent PMSG treatment at $\mathrm{L}_{18}, \mathrm{~L}_{25}$ and $\mathrm{L}_{\mathbf{3 2}}$. The number of piglets at the time of injection was not noted for all sows treated at $\mathrm{L}_{18}, \mathrm{~L}_{25}$ and $\mathrm{L}_{32}$.

On the other hand, for half the sows treated at $\mathrm{L}_{26}$, a reduced number of $\mathbf{r}$ to 5 piglets was left with the mother from the Ioth day of lactation; the rest of the litter was reared artificially.

Oestrous detection was carried out twice daily from the day after PMSG injection.

Females in oestrus were inseminated twice on the first and second days of oestrus with $4 \times 10^{9}$ spermatozoa. In the sows treated on the 32 nd day of lactation, and in some of those treated at $\mathrm{L}_{18}$, artificial insemination was carried out systematically on the $4^{\text {th }}$ and $5^{\text {th }}$ days after PMSG. A coelioscopic examination of the ovaries was performed, during the ten days following insemination, on some of the sows treated at $\mathrm{L}_{\mathbf{1 6}}, \mathrm{L}_{18}$ and $\mathrm{L}_{\mathbf{2 5}}$. Weaning was at a fixed clate, either 21 or 3 I days after PMSG.

\section{RESULTS}

\section{I. - Appearance of oestrus}

Respectively, 33.3, 57.0 and $74.2 \mathrm{p}$. Ioo of sows treated at the I6th (suckling more than 6 piglets), I 8 th and $25^{\text {th }}$ days of their lactation came into oestrus between the 3 rd and 7 th days after injection of PMSG - the maximum number on the 4 th and 5 th days : 45.8 p. Ioo if the hormone was injected at $L_{18} ; 6 \mathbf{I} .4$ p. Ioo if PMSG was injected on the 25 th day of lactation (table $I$ ). Thus, the response, is better when the treatment is given later in lactation $(\mathrm{P}<\mathrm{O} . \mathrm{OI})$. No detection of oestrus was possible for the hormone treatment carried out at $\mathrm{I}_{42}$.

TABLE, I

Oestrus response after PMSG injection (2 ooo IU)

$\mathrm{L}_{0}=$ day of farrowing

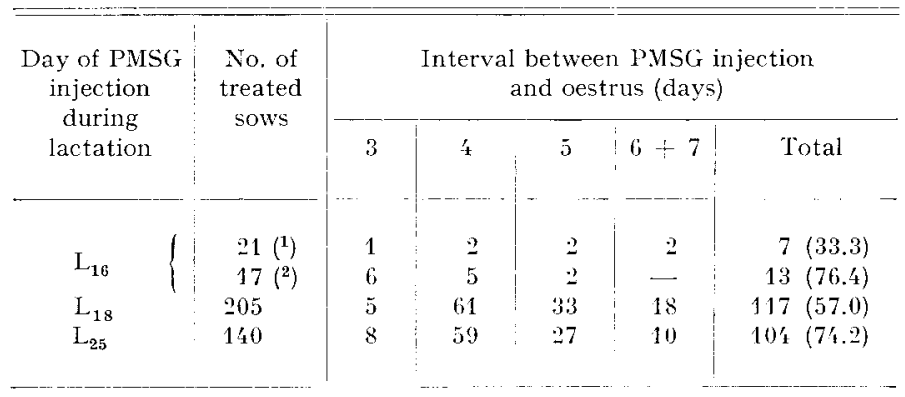

(1) Sows suckling more than 6 piglets.

(2) 1-5 piglets left with the sow from the 10th day of lactation.

() Percentages calculated in comparison with the number of sows treated. 
In addition, the induction of oestrus seems to depend on the size of the suckled litter at the time of treatment. If litter size is increased from 5 to 10 , the percentage of sows in oestrus decreases : at $\mathrm{L}_{18}$, it decreases from 77.3 to $46.8 \mathrm{p}$. I00 $(\mathrm{P}<0.05)$. This diminution is similarly noted for treatments at $\mathrm{L}_{16}(\mathrm{P}<0.05)$ and $\mathrm{L}_{25}(\mathrm{NS})$ (table 3). On the other hand, if only I to 5 piglets are left with the mother from the Ioth dayof lactation, the same proportion of sows come in oestrus, after an injection of PMSG at $\mathrm{L}_{16}, \mathrm{~L}_{18}$ and $\mathrm{L}_{25}$ and are $76.4,77 \cdot 3,58.3 \mathrm{p}$. Ioo respectively.

\section{2. - Ovulation (table 2)}

A coelioscopic examination of the ovaries was performed ten days after the injection of PMSG. A low percentage of females in oestrus are ovulating, whatever the time of PMSG injection. In fact, among the sows in oestrus after a PMSG treatment at $\mathrm{L}_{16}$ (suckling more than 6 piglets), $\mathrm{L}_{18}$ and $\mathrm{L}_{25}$, only $7 \mathrm{I} .4,4 \mathrm{I} .6$ and $75.0 \mathrm{p}$. Ioo of these had corpora lutea on both ovaries. The ovulation rate varied between 19.8 and 24.2. The frequency of silent ovulations is higher at $L_{16}$ (IO.O p. IOo) than at $L_{18}$ ( 3.2 p. IOo) ; none was noted at $\mathrm{I}_{25}$.

If the size of the suckled litter is diminished, the proportion of sows showing induced oestrus and ovulating after PMSG injection at $L_{16}$ is around Ioo $p$. IOo; the nean number of corpora lutea per female is 27.8 in this case.

TABLE 2

Infuence of the PMSG injection (2000 IU) on the rate of ovulated sows (coelioscopic ovarian examination)

$\mathrm{L}_{0}=$ day of farrowing

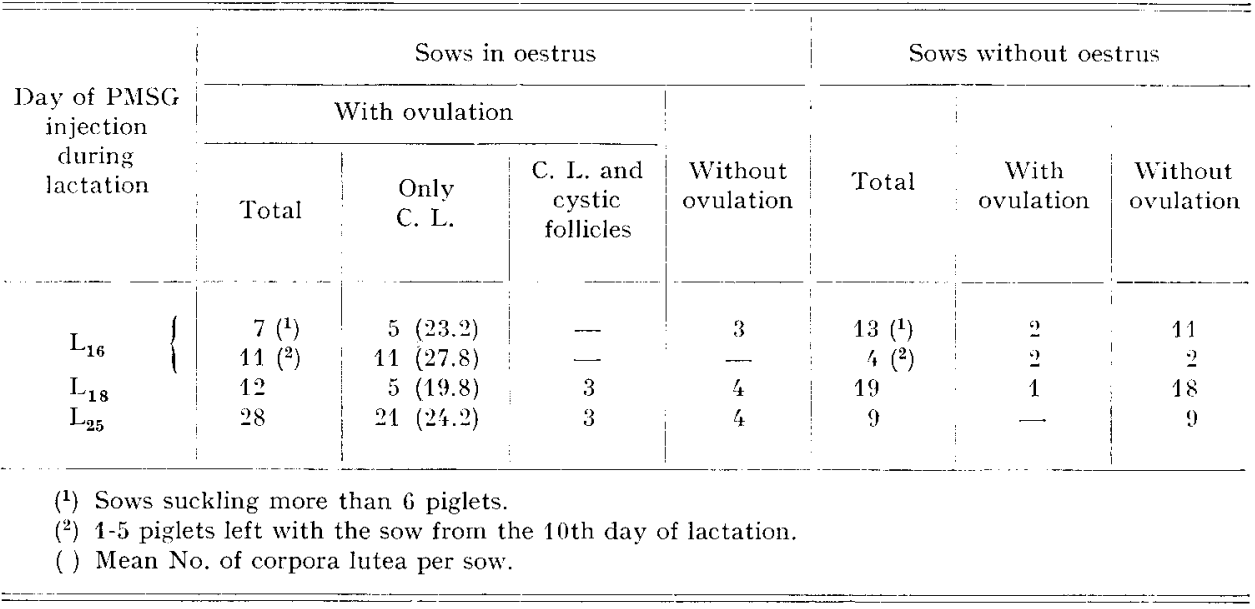

\section{3. - Farrowing rate and prolificity (obtained after induced oestrus)}

The time of PMSG injection during lactation modifies significantly the farrowing rate : I9.0 p. IOO and $25.4 \mathrm{p}$. IOO of sows treated at $\mathrm{L}_{\mathbf{1 6}}$ (suckling more than 6 piglets) and $L_{18}$ give birth, against $34 . \mathrm{I}$ and $45.8 \mathrm{p}$. Ioo in the case of injection 7 or I4 days later (table 3 ). 
The size of the suckled litter at the time of PMSG injection is also related to the fertility : at $\mathrm{L}_{18}$, if the number of suckled piglets increases from 5 to ro the farrowing rate decreases from 63.6 to 22.6 p. roo $(\mathrm{P}<\mathrm{o} .0 \mathrm{I})$. This decrease under the influence of litter size is also observed for the treatment at $\mathrm{L}_{16}$ as for that at $\mathrm{L}_{25}$ (NS). The time of treatment does not appear to have an influence on the prolificity. The mean litter size are for the four treatments respectively : 9.2, II.I, I0.3, 9.9 piglets per sow after systematic $\mathrm{AI}$ at the induced oestrus (table 3 ).

\section{TABLE 3}

Influence of the number of suckled piglets on the pregnancy rate of treated osws $\mathrm{L}_{0}=$ day of farrowing

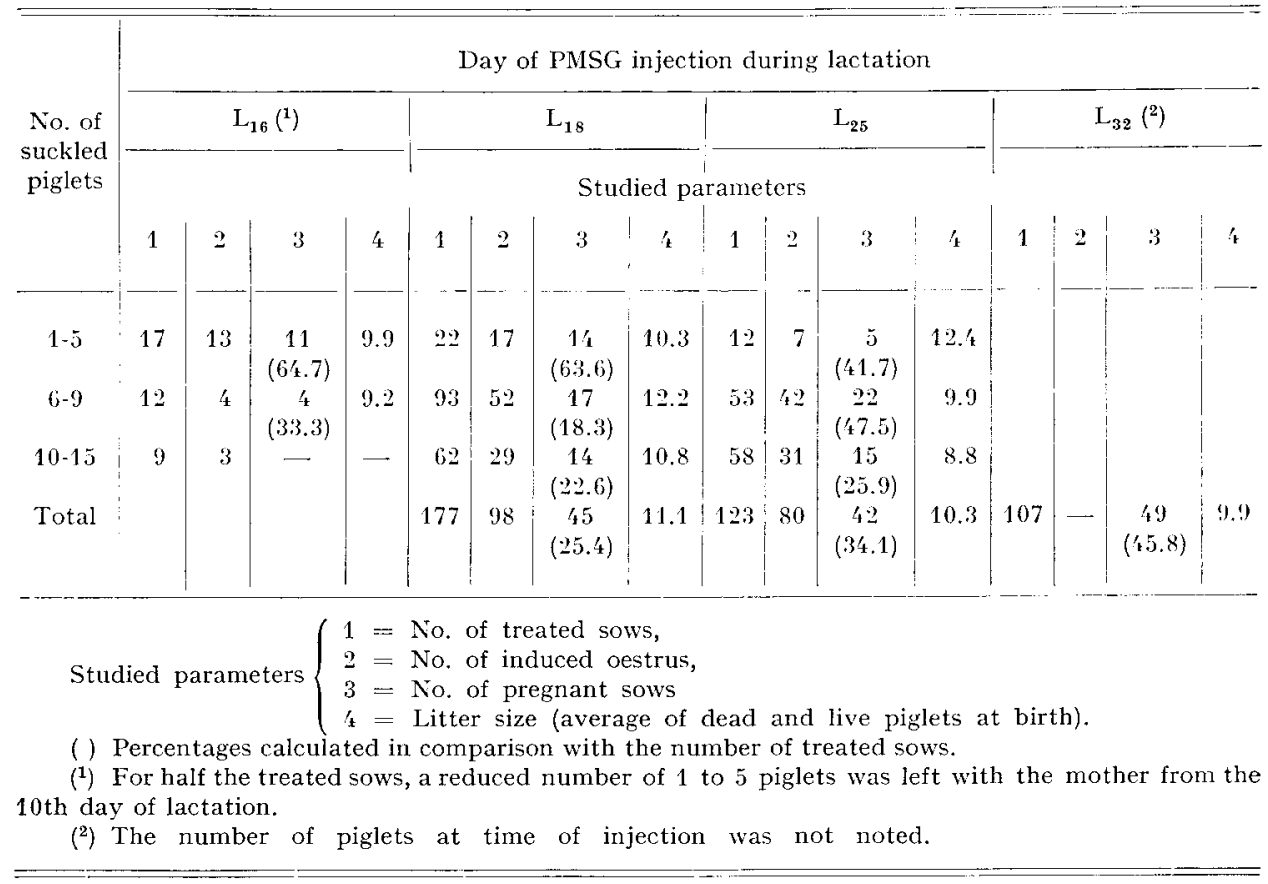

For the females treated at $\mathrm{L}_{\mathbf{1 6}}$, if the piglets are removed from the mother at Io days of lactation, the farrowing rate increases significantly $(64.7 \mathrm{p}$. Ioo) in comparison with that calculated when the females keep all their piglets (more than 6 in this case) during the whole lactation period (I9.0 p. I0o). Prolificity does not differ between treatments.

\section{DISCUSSION}

It is possible to induce oestrus and ovulation in lactating sows by a single injection of PMSG (2 ooo IU) carried out on the I6th, I8th, $25^{\text {th }}$ or 32 nd day after parturition. However, the ovarian response is dependant on the time of injection of PMSG and on the size of the suckled litter at this time. 
It appears difficult to induce gestation early enough in lactation when the sow suckles more than 6 piglets. In fact, an examination of the ovaries Io days after artificial insemination has shown that the proportion of sows which ovulate is low in sows treated at $L_{16}$ and $L_{18}$.

This could explain in part, the variability of results quoted in the literature (AliLEN and $a l .$, I957 ; CRIGHTON, I968; I970 $a$; I97c $b$; KUDLAC, I962 ; EPSTEIN and KADMON, I969; Martinat and al., I972; I974) since few authors have taken account of the parameters indicated above.

However, if the size of the suckled litter is controlled by removing some of the piglets from the Ioth day of lactation, the percentage of pregnant sows after injection of PMSG at $\mathrm{L}_{10}$ is little different from that found after immediate weaning.

ROWLINSON and BRYANT (I974) have shown that, under natural conditions (without hormone treatment and without control of the size of the suckled litter), the grouping at 3 weeks of lactation until weaning ( 6 weeks) of 3 to 8 sows with their litters in the same covered yard provokes an oestrus and a gestation during lactation in 98.2 p. Ioo of animals. However, the appearance of oestrus is spred over a period of Io days, on average, after the grouping.

Why then, could one not envisage to leave 3 or 4 piglets with the mother until ten days of lactation, to re-group the sows with their piglets after an injection of 2 ooo IU of PMSG, weaning taking place at a fixed date?

Colloque: Control of sexual cycles in domestic animals October 27-30, 1974, Nouzilly.

\section{ACKNOWLEDGEMENT}

This study was carried out with financial help from FORMA under an agreement between the I. T. P. and I. N. R. A. The endoscopies were performed by A. Locatelli, to whom I wish to express my thanks. Others to whom thanks are due for help in this study are J. L. Bors, P. Despres, J. Gautier, Y. Lebreton.

\section{RÉSUMÉ,}

\section{INDUCTION DE IA GESTATION PENDAN'T LA LACTATION CHEZ LA TRUIE}

L'injection de 2 ooo IU de PMSG permet d'induire l'cstrus et l'ovulation chez la truic allaitante. Mais la réponse de l'ovaire dépend du moment de l'injection de PMSG et de la taille de la portée allaitée.

Pour induire une gestation très tôt au cours de la lactation (vers le I $6^{\mathrm{e}}$ jour) il faut enlever une partie des porcelets à la mère avant l'injection de PMSG. S'il ne reste que I-5 porcelets, 76,4 p. Ioo des truies entrent en ostrus 3 à 7 jours après l'injection et ovulent. La fertilité est comparable à celle des truies sevrées 3 à 5 semaines après parturition.

\section{REFERENCES}

Allen A. D., Lasley J. F., URen A. W., 1957. The effects of gonadotrophic hormone injections on induction of oestrus in lactating sows. J. Anim. Sci., 16, I097 (Abstr.).

Crighton D. B., rg68. The induction of oestrus and ovulation during the lactational anoestrus of the sow. VI Cong. intern. Reprod. anim. Insem. artif., Paris, vol. II, I4I5-I4I7. 
Crighton D. B., Lamming G, E., I969. The lactational anoestrous of the sow : the status of the anterior pituitary ovarian system during lactation and after weaning. J. Endocr., 43, 507-519.

CRIGHTON D. B., I970. The induction of pregnancy during lactation in the sow. J. Reprod. Fert., 22, $223-23 \mathrm{~T}$.

CRIGHTON D. B., I970. The induction of pregnancy during lactation in the sow : the effects of a treatment imposed at $2 \mathrm{I}$ days of lactation. Anim. Prod., 12,61 $1-617$.

Epstein H., Kadmon S., r969. Physiological and economic feasibility of hormonally induced ovulation in lactating Large White sows. J. A gric. Camb., 72, 365-370.

Heitman H., Cole H. H., I956. Further studies in the induction of estrus in lactating sows with equine gonadotrophin. J. Anim. Sci., 15, 970-977.

Kudlac E., I962. Uyvoláni rije u pnasnic v oldobi laktace. Vet. Med., Praha, 35, 507-5I2.

Lauderdale J. W., Kirkpatrick R. L., First N. L., Hauser E. R., Casida L. E., ig65. Ovarian and pituitary gland changes in periparturient sows. J. Anim. Sci., 24, I Ioo-i Io3.

Martinat F., Legault C., du Mesnil du Buisson F., i972. Induction d'une gestation pendant la lactation chez la Truie. Journées Rech. porc. en France, Paris, 37-43.

Martinat-Botte F., du Mesnil du Buisson F., Bariteau F., Mavlíon P., igł4. Induction d'une gestation pendant la lactation. Comparaison de deux moments d'injection de PMSG. Journées Rech. porc. en France, Paris, 37-4I.

Melampy R. M., Henricks D. M., Anderson L. L., Chen C. L., Schultz J. Rig66. Pituitary follicle stimulating hormone and luteinizing hormone concentrations in pregnant and lactating pigs. Endocrinology, 78,80I.

Palmer W. M., Teague H. S., Venzke W. G., I965. Macroscopic observations on the reproductive tract of the sow during lactation and early post weaning. J. Anim. Sci., 24, 54r-545.

Rowlinson R., Bryant M. J., I974. Rebreeding sows during lactation. L-A system for overcoming lactational anoestrus with special reference to the effects of the male. $3^{\mathrm{e}}$ Cong. intern., Lyon, $\mathrm{C}_{5}$ (Abstr.). 